\title{
Guds børn og Fadervor (II)
}

\section{Bibeloversættelse og Abba-råb ifølge N.F.S. Grundtvig}

\author{
Lektor, dr. theol. \\ Nils Arne Pedersen, Aarhus Universitet
}

\begin{abstract}
In the baptismal ritual of the Danish Church, the Lord's Prayer has since 1912 been placed after baptism while it formerly was placed before, as in Luther's Taufbüchlein. Two consecutive articles argue that the replacement in 1912 was influenced by Nikolai Frederik Severin Grundtvig's theology. The present second article deals with the different translations of Biblical passages central to the baptizee as a child of God, and attempts to demonstrate that Grundtvig identified the Lord's Prayer with the Abba-cry mentioned in Romans 8:15 and Galatians 4:6. Thus, the Lord's Prayer had its role to play after baptism and furthermore functioned for the believer as a daily confirmation and an inner assurance of salvation.
\end{abstract}

Key Words: N.F.S. Grundtvig - Baptism - Lord's Prayer - Children of God - Bible Translation - Abba Father

\section{Indledning}

Sætningen, "hvori du gør os til dine børn", har givet anledning til debat i Folkekirken. ${ }^{1}$ Den falder i begyndelsen af dåbsritualet og blev indført af biskopperne i dåbsritualet i 1912 i sammenhæng med, at Fadervor blev flyttet hen efter selve dåben for at udtrykke, at den døbte nu var optaget blandt dem, der havde ret til at bede Guds børns bøn, og indlemmet i samfundet af dem, med og for hvem Fadervor bedes. Den teologihisto-

1. Denne artikel er anden del af en undersøgelse af Grundtvigs syn på Fadervor i forbindelse med dåben, foranlediget af netop denne debat. Første del af undersøgelsen: Nils Arne Pedersen, "Guds børn og Fadervor (I): Dåbsritualets led og rækkefølge ifølge N.F.S. Grundtvig” findes i DTT 83/3-4 (2019), 99-120. - Det havde ikke været muligt at skrive dette arbejde uden en afgørende hjælp og støtte fra min bror, lic. theol. Kim Arne Pedersen, for hvilken jeg takker hjerteligt. - I det følgende benyttes disse forkortelser: GSV = N.F.S. Grundtvig, Sang-Vark til den danske Kirke, 1-5 (København: G.E.C. Gad 1982-1984); US = N.F.S. Grundtvigs Udvalgte Skrifter ved Holger Begtrup, I-X (København: Gyldendal 1904-1909); $\mathrm{VU}=$ N.F.S. Grundtvig, Verker $\mathrm{i}$ Udvalg ved Georg Christensen og Hal Koch, I-X (København: Gyldendal 1940-1949). Ordbog over det danske Sprog 1-27 (København: Gyldendalske Boghandel \& Nordisk Forlag 1919-1954) forkortes ODS 1-27. 
riske baggrund for disse tanker findes hos det 19. århundredes grundtvigianere, men der er ikke enighed i forskningen, om de også kan føres tilbage til Grundtvig selv. Med henblik på at afklare dette spørgsmål var det nødvendigt bredere at belyse Grundtvigs syn på dåbsritualet. Det blev påvist, at Grundtvig betragtede døbeordene og vandoverøsningen som nådemidlet, som ritualets sakramentale centrum, men desuden at det ikke giver mening at sige, at Grundtvig var "bundet" til sin samtids dåbsritual fra 1783 ("Guds børn og Fadervor (I)"). Han forholdt sig selvstændigt og kritisk til det samtidige ritual og søgte at bestemme, hvad der var dåbens oprindelige form, indstiftet af Jesus selv. Her mente Grundtvig at kunne drage historiske slutninger fra den teologiske betydning, som han fandt i dele af ritualet, men motiver fra Bibelen, der lignede ritualets led, fungerede desuden som støtteargumenter, og Grundtvig inddrog også ældre dåbsritualer i sine overvejelser.

Argumenterne fra Bibelen er ikke overraskende, for selv om den kirkelige anskuelse betød, at Grundtvig distancerede sig fra det lutherske syn på skriften, blev han alligevel ved at være en bibelsk teolog; citater og hentydninger til steder i skriften er centrale i hans teologiske forfatterskab og salmer. Hvad angår temaet "Guds børn og Fadervor", findes der en gruppe af steder og termer i det Nye Testamente, som nærværende anden del af artiklen vil søge at vise var af afgørende betydning for Grundtvigs syn på Fadervor i forbindelse med dåben. Det drejer sig om passagerne om Guds børn i Johannesevangeliet og hos Paulus, og råbet "Abba Fader!" hos denne. For fuldt ud at kunne forstå, hvornår Grundtvig hentyder til disse passager, og hvad han bruger dem til, er det imidlertid i første omgang nødvendigt at beskæftige sig med det noget tekniske spørgsmål om bibelstedernes oversættelse - hvordan de var oversat i Grundtvigs samtid, og hvordan han selv oversatte dem. Resultaterne er nødvendige for fuldt at kunne forstå, hvad Grundtvig taler om i en række tekster, der inddrager passagerne fra Johannesevangeliet og Paulus.

\section{Oversættelsen af passager i Johannes og Paulus af central betydning for temaet "Guds børn og Fadervor"}

En række passager i Johannesevangeliet og Paulus ser ud til at have spillet en vigtig rolle i Grundtvigs overvejelser om "Guds børn og Fadervor". Først vil jeg kort præsentere de nævnte passager, som de i foreligger i det græske Nye Testamente. Dernæst følger en undersøgelse af, hvordan de blev oversat til dansk i de oversættelser fra Bibelen, som Grundtvig benyttede, og hvordan Grundtvig selv oversatte dem. 
For det første er Joh 1,12-13 vigtig. Her er der tale om, at Kristus

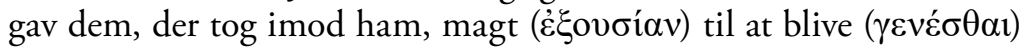
Guds børn ( $\tau \dot{\varepsilon} \kappa v \alpha \theta \varepsilon$ ṽ̃), dvs. dem, der tror på hans navn, som er

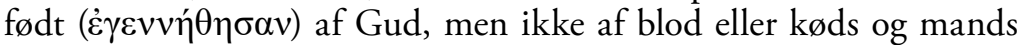
vilje. Versene må skulle forstås sammen med Joh 3,3-6 (samtalen med Nikodemus), som er det eneste andet sted i Johannesevangeliet, hvor $\gamma \varepsilon v v \alpha ́ \omega$ bruges om frelsen og modstilles en fødsel af kød, og hvor der éntydigt tales om dåben, at blive født af vand og ånd.

For det andet, og særligt vigtigt, er råbet $\alpha \beta \beta \alpha$ ó $\pi \alpha \tau \eta ́ \rho$ i Rom 8,15 og Gal 4,6, da det er en eksegetisk mulighed, at det sigter til Fadervor. $^{2}$ Dette råb er direkte forbundet med tanken om de kristne som Guds børn: Se således sammenhængen mellem vioì ( $\tau$ oṽ) $\theta \varepsilon \circ \tilde{v} / \tau \varepsilon ́ \kappa v \alpha$ ( mellem vioì $\theta \varepsilon$ ov, troen og dåben i Gal 3,26-28, og videre udtrykket

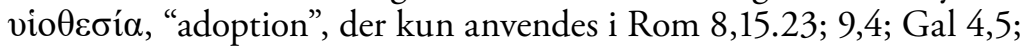
Ef 1,5, og som egentlig er en juridisk teknisk term, hos Paulus kun brugt om religiøse forhold, ${ }^{3}$ herunder udvælgelsestanken (Rom 9,4).

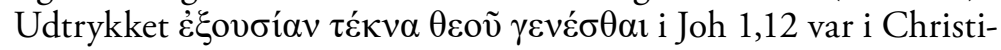
an VI-Bibelen fra 1740 blevet oversat som "magt at blive Guds børn”. Oversættelsen rummede her krydshenvisninger til Rom 8,15.16.17; Hos 1,10 (= 2,1); Gal 3,26; 1 Pet 1,14; 2 Pet 1,4; 1 Joh 3,1. ${ }^{4}$ Allerede disse henvisninger henledte således læserens opmærksomhed på sammenhængen med bl.a. stederne i Romer- og Galaterbrevet.

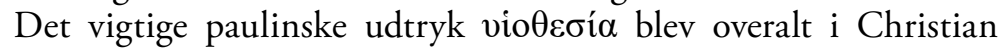
VI-Bibelen oversat som "sønlig udkaarelse", en oversættelse der allerede da var traditionel. ${ }^{5}$ I 1819 var 1740-oversættelsen blevet revi-

2. Se fx Joachim Jeremias, Abba. Studien zur neutestamentlichen Theologie und Zeitgeschichte (Göttingen: Vandenhoeck \& Ruprecht 1966), 55 n. 106; Otto Michel, Der Brief an die Römer, KEK IV (Göttingen: Vandenhoeck \& Ruprecht 1978), 260-261; Robert Jewett og Roy D. Kotansky, Romans. A Commentary. Hermeneia (Minneapolis: Fortress Press 2007), 499.

3. Se Walter Bauer, Griechisch-Deutsches Wörterbuch zu den Schriften des Neuen Testaments und der übrigen urchristlichen Literatur (Berlin \& New York: De Gruyter 1971), 1649ff.: "die Annahme an Kindes Statt, d. Adoption".

4. Jeg benytter 1780-optrykket af Christian VI-Bibelen af Ny Testamente: Vor Herres og Frelseres Jesu Christi Nye Testamente, Med Fliid og efter Grund-Texten efterseet og rettet, Saa og med Mange Paralleler og udforlige Summarier forsynet (Kjøbenhavn: Udi det Kongel. Waysenhuses Bogtrykkerie, og paa dets Forlag 1780).

5. Således Christian VI-Bibelen (1780). Christian VI-Bibelen var en revision af den Resen-Svaningske Bibel: Det Ny Testamentis Bøgger, paa Danske, Igennem seete med fliid effter den Grakiske text, det negste mueligt Var, Effter vor allernaadigste Herris K. Christians den IV. Christelige Befalning (Kiøbinghaffn 1647). Denne oversættelse havde dog ikke det ensartede "sønlig udkaarelse", men fulgte helt Hans Poulsen Resens lidt mere varierede gengivelse i Det Ny Testamentis Bøggerl paa Danskel Igeñem seete med fliid effter den Grakiske text/ det negste mueligt vaarl oc effter som de paa 
deret, men Grundtvig havde kritiseret denne oversættelse, ${ }^{6}$ og selv benyttede han et optryk fra 1787 af Christian VI-Bibelen, som han havde fået foræret af Constance Steensen de Leth, men læste desuden Det Nye Testamente fra den græske grundtekst. ${ }^{7}$

Ved siden af 1740-oversættelsen forelå der imidlertid en anden oversættelse i alterbogens perikoper. Gustav Albeck har argumenteret for, at Hans Bagger, da han i 1688 reviderede Peder Palladius' alterbog, beholdt mange udtryk fra Christian III's Bibel, selv om han også hentede udtryk fra den Resen-Svaningske oversættelse og på egen hånd moderniserede udtryksformen, og denne Hans Bagger-version forelå endnu i alterbogen fra $1812,{ }^{8}$ og Grundtvig var sandsynligvis klar over dens sammenhæng med Christian III's Bibel (Albeck

andre atskillige Tungemaal vaare best udsatte. Effter vor allernaadigste Herris K. Christian den IV. Christelig Befalning. (Kiøbinghaffn: 1607), der havde oversat Rom 8,15 med "en sønlig udkaarelsis Aand"; Rom 8,23; 9,4 "sønlig udkaarelse”; Gal 4,5 "Børnenis udkaarelse"; Ef 1,5 "Børns udkaarelse". Tydeligvis var Resen igen inspireret fra Christian III's Bibel, der havde "sønlig Aand" i Rom 8,15, "børnenis vdkaarelse" i Rom 8,23, "Børnenis vdkaarelse" i Rom 9,4, "Børnens vduælelse" i Gal 4,5, "Børns vdkaarelse" i Ef 1,5, Det ny Testamente paa Danske (Københaffn: Ludowich Dietz 1550). Det er interessant, hvorfra oversættelsen "udkårelse", der ikke er en ueffen gengivelse af "adoption", stammer, for Luther (1522) havde oversat Rom 8,15 med "kindlichen geyst" og ellers overalt med "kindschafft", og "udkårelse" findes ikke hos Christiern Pedersen (Det Ny Testamente Ihesu Christi egne ord oc Euangelia, som han selff predickede oc larde her paa Jorden, Hwilke hans hellige Apostle och Euangelister siden bescreffue, Andorp: Willem Vorsterman 1531): "sønnelig aand" i Rom 8,15 , "ath bliffue Guds Børn” i Rom 8,23, "Guds Børnis arff” i Rom 9,4, "Børnenis arff” i Gal 4,5, "Han vdualde oss och til sine Børn” i Ef 1,5. Se Peter Skautrup, "Reformationsbiblens tilblivelse og forudsætninger. Forskningens problemer og resultater", Bidrag til Den danske Bibels Historie. Festskrift i Anledning af den danske Bibels 400 Arr Jubilaum, red. Bertil Molde (Aarhus: Rosenkilde og Baggers Forlag 1950), 42-58 vedrørende Christian III-Bibelens komplicerede tilblivelse.

6. Vor Herres og Frelsers Jesu Christi Nye Testament, ved Kong Frederik den Siettes christelige Omsorg med Fliid efterseet, og rettet efter Grundtexten, saa og med mange Parallelsteder og udforlige Indholdsfortegnelser forsynet (Kiøbenhavn: Det Kongl. Vaisenhuses Forlag 1819). Se om Grundtvigs kritik i Gustav Albeck, "Grundtvigs Forsøg som Bibeloversætter”, Bidrag til Den danske Bibels Historie. Festskrift i Anledning af den danske Bibels 400 Års Jubilaum, red. Bertil Molde (Aarhus: Rosenkilde og Baggers Forlag 1950), 148-150, 154-160, 166-167.

7. Christian Ludwigs, "Grundtvigs bibel”, Højskolebladet (1919), 501-508. Vedrørende Grundtvig som bibeloversætter se desuden Albeck (1950); idem, "Grundtvigs Syn paa Jens Møllers 'Bidrag til en Oversættelsestheorie med nærmest Hensyn til de bibelske Skrifter”, Grundtvig Studier (1957), 25-35; Jette Holm et al. (udg.), Nypagts-Bogen. Grundtvigs nytestamentlige oversattelser. Skrifter udgivet af Grundtvig-Selskabet XLI, Palmeserien 11 (København: Fønix 2018).

8. Forordnet Alter-Bog udi Dannemark og Norge, hvori findes de nyelig allenaadigst giorte Forbedringer (Kiøbenhavn: Den Gyldendalske Boghandlings Forlag 1812), herefter forkortet: Forordnet Alter-Bog (1812), som Grundtvig selv var i besiddelse af, jf. "Guds børn og Fadervor (I)", 102, note 7. 
(1950), 153-154). Joh 1,12-13 fandtes dog ikke mellem perikoperne. Af interesse er imidlertid følgende episteltekster: Ved Gal 4,1-8 til julesøndag havde Forordnet Alter-Bog (1812), 20 "Børnenes udkaarelse" i 4,5 ligesom den Resen-Svaningske Bibel; ved Rom 8,18-24 til 4. søndag efter trinitatis havde Forordnet Alter-Bog (1812), 113-114 "Børnenes Udkaarelse" i 8,23 ligesom Christian III's Bibel; og endelig ved Rom 8,12-18 til 8. søndag efter trinitatis havde Forordnet Alter-Bog (1812), 124-125 i 8,25 “sønlig Udkaarelses Aand” ligesom både Christian VI-Bibelen og den Resen-Svaningske Bibel. I 1783 var udtrykket "sønlig udkaarelse" desuden kommet til at indgå i dåbsritualet, idet biskop Nicolai Edinger Balles indledning citerede Ef 1,5 fra Christian VI-Bibelen: "og haver beskikket os i ham til sønlig Udkaarelse efter sin Villies Velbehagelighed".

Over længere perioder (c. 1810-1820, 1844, 1853) oversatte Grundtvig imidlertid også selv dele af det Nye Testamente, som han ikke offentliggjorde, men som for nylig er blevet publiceret samlet (Holm et al. (2018)). Derimod offentliggjorde han egne oversættelser af perikopetekster i sine Christelige Pradikener eller Søndags-Bog I-III (Kiøbenhavn: Wahlske Boghandlings Forlag 1827-1830).

I disse oversættelser findes også nogle af de passager, der er af interesse her. Blandt de håndskrevne oversættelser, som Grundtvig ikke selv publicerede, findes allerede en tidlig oversættelse af Joh 1,1-28

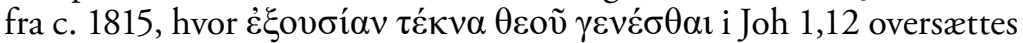
"Rettighed til at være Guds Børn" (Holm et al. (2018), 150), samt to langt senere oversættelser af Efeserbrevet. Den første fra 1844 over-

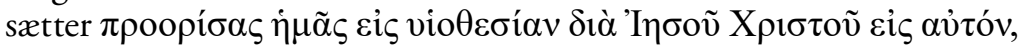

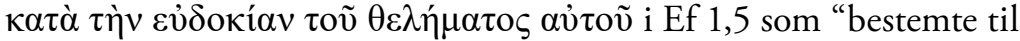
Børne-Kaar hos Ham, ved Jesus Christus, efter sin behagelige Villie" (Holm et al. (2018), 116), medens den anden fra 1853 oversætter "(thi) efter sin velbehagelige Villie har Han bestemt os til Børnekaar hos Sig ved Jesus Christus".

Et bredere grundlag får vi, når vi ser på perikopeoversættelserne i Christelige Pradikener eller Søndags-Bog (1827-1830); i bind I,

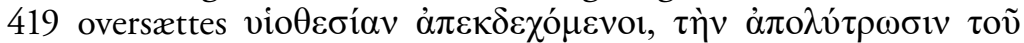
$\sigma \omega ́ \mu \alpha \tau o \varsigma \dot{\eta} \mu \tilde{\omega} v$ i Rom 8,23b som "forventende med Barne-Vilkaar vort Legems Igienløsning!” I bind II, 511 oversættes $\alpha \lambda \lambda$ ’ غ̇ $\lambda \alpha \dot{\beta} \varepsilon \tau \varepsilon$

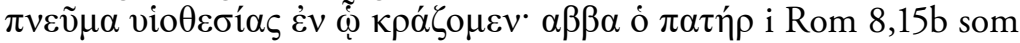
"men have annammet Barnlighedens Aand, hvori vi udbryde: Abba, vor Fader!” Disse oversættelser sandsynliggør, at Grundtvig har fundet oversættelsen af vio $\theta \varepsilon \sigma i ́ \alpha$ som “sønlig/børnenes udkårelse" tung

9. Forordnet Alter-Bog (1812), 242, sml. bibeloversættelsen (1780): "Som forud beskikkede os til sønlig udkaarelse, formedelst JEsum Christum, til sig selv, efter sin villies velbehagelighed." 
og gerne har villet gengive ordet som "børnekår", "barnevilkår” eller "barnlighed" - lutter nydannelser i forhold til den danske oversættelsestradition. Når Grundtvig gengiver Rom 8,15b som "Abba, vor Fader!”, synes han desuden at identificere Abba-råbet med Пó $\tau \varepsilon \rho ~ \eta ं \mu \tilde{\omega} \nu$ i Matt 6,9.

At Grundtvig selv forsøgte sig som oversætter, betyder ikke, så vidt jeg kan se, at han fuldstændig opgav de ældre oversættelser; hans egne forsøg var jo udkast, der aldrig blev udmøntet i en færdig oversættelse. Det virker, som om de blev brugt supplerende til at forklare og nuancere den traditionelle oversættelse. I GSV 4, No. 271,5 ("Lyksaligt det Folk, som har Øre for Klang/ Herovenfra!”) fra 1852/53 hentyder Grundtvig tydeligvis både til den officielle oversættelse og sin egen:

\section{Lyksaligt det Folk, som har Jesus til Drot,/ Marias Søn!/ Som Søskende hans har de alle det godt/ I Lys og Løn:/ Guds-Freden i Hjerte, Guds Ord i Mund,/ Med Herligheds-Haabet i allen Stund, Thi de, som Gud-Faders Udkaarne/ Har Børnekaar med Hans Eenbaarne!}

Meningen er klart nok, at de døbte som Gud Faders adopterede børn er blevet søskende til hans enbårne, evige Søn; dermed har de fået dåbsgaverne, dvs. fredlysningen, mundsordene og Fadervor, som der sigtes til med herligheds-håbet (jf. Kol 1,27). "Børnekaar" gengiver

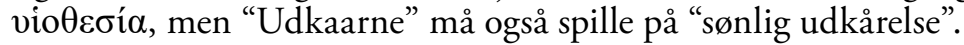

Samme tendens til at kombinere traditionelle og egne oversættelser er til stede i Grundtvigs prædikener fra 1839-1842, der blev udgivet for nogle år siden. ${ }^{10}$ Når Grundtvig i 1815 oversatte Joh 1,12 som "Rettighed til at være Guds Børn", kunne man forvente at finde noget lignende i disse prædikener, men her foretrækker Grundtvig den mere traditionelle oversættelse "Magt til at være Guds Børn" (bd. 1, 16, 351; bd. 3, 45, 306, 330). Imidlertid viser det sig, at Grundtvig i Joh 1,13 følger Irenæus' (Adv. Haer. III,16,2) og Tertullians (De carn. Chr. 24,2) læsemåde: qui ... natus est $\mathrm{i}$ stedet for oî ... Ė $\gamma \varepsilon v v \eta \dot{\theta} \theta \eta \sigma \alpha v$ : "til at være Guds Børn i Ham, den Eenbaarne, der ikke fødtes af Mands eller af Kiøds Villie, men af Gud!" (Holm et al. (2003), bd. 1, 24). I 1815 havde Grundtvig ellers oversat fra den græske tekst (Holm et al. (2018), 150). Man kunne sige, at tekstvarianten, der næppe er den oprindelige læsemåde, gør sammenhængen mellem Joh 1,12-13 og dåben mindre tydelig, fordi der ikke mere er en oplagt sammen-

10. Jette Holm et al. (udg.), Grundtvig: Pradikener i Vartov, bd. 1: 1839-40, Fra 2. søndag efter trinitatis 1839 (Grundtvigs indsattelse $i$ Vartov); bd. 2: Kirkeåret 184041; bd. 3: Kirkeåret 1841-42; bd. 4: Christian Thodberg, Indledning og kommentar til Grundtvigs predikener i Vartov 1839-42 (bind 1, 2 og 3) (København: Forlaget Vartov 2003). 
hæng med Joh 3,3-6. Ikke desto mindre var sammenhængen mellem Joh 1,12 og dåben fortsat en sikker sag for Grundtvig (se Holm et al. (2003), bd. 3: 45, 306, 330).

"Børneret" bruges et enkelt sted som en gengivelse af vio $\theta \varepsilon \sigma i ́ \alpha$ i Gal 4,5 (Holm et al. (2003), bd. 1: 98, måske også 133, 443; bd. 2: 74, 238, 254, 283). "Barne-Kaaret" er et andet udtryk (ibid., bd.

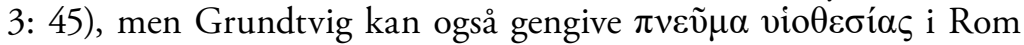
8,15 som "den barnlige Udkaarelses Aand" (ibid., bd. 1: 194), "den guddommelige Barnligheds, den sønlige Udkaarelses Aand” (ibid., bd. 3: 214), "en sønlig Udkaarelses (en Barnligheds) Aand" (ibid., bd. 3: 305), "den guddommelige Barnligheds Aand ... den sønlige Udkaarelses, den himmelske Barnligheds Aand” (ibid., bd. 3: 306), "Barnlighedens Aand" (ibid., bd. 3: 307).

Det væsentligste resultat af denne undersøgelse er, at Grundtvig kombinerede de officielle oversættelser med sine egne. Det betyder, at han ikke kun hentyder til adoptionen som Guds børn, vio $\theta \varepsilon \sigma i ́ \alpha$, når han benytter den officielle oversættelse "Udkaarelse", men også når han benytter udtryk som "Børnekaar".

\section{Abba Fader hos Grundtvig}

Nu er det værd at bemærke, hvad Paulus-teksten siger: Fordi vi ifølge Rom 8,15 har fået Helligånden, udkårelsens Ånd, kan vi i den råbe Abba; Gud har ifølge Gal 4,6 sendt sin Søns Ånd i vore hjerter, og den råber Abba. Hvis Grundtvig forstod dette Abba-råb som Fadervor, må vi antage, at det måtte blive et problem, at Fadervor i dåbsritualet blev bedt før dåben, hvor dåbskandidaten endnu ikke havde modtaget Helligånden og var blevet Guds barn. Problemet er klart i GSV 1, No. 88,12-13 (fra 1837):

12: Barne-Troen før sin Daab/ Stammer vel paa Abba-Raab,/ Finder, uden Barne-Kaar,/ Dog for dristigt Fader-Vor,/ Fattes og den Tillid stor,/ Som er Sjælen i det Ord:/ Skee din Vilje med vor Jord! 13: Først naar Fader-Aanden god/ Sætter os paa Barne-Fod,/ Med den Guders Gud og Drot,/ Som giør Alting saare godt,/ Hjertet kan med Stemme fiin/ Efternynne Herre sin:/ Skee din Vilje, ikke min!

"Barne-Kaar" er jo, som vi har set, en oversættelse af vio $\theta \varepsilon \sigma i ́ \alpha$, dvs. adoptionen som Guds børn i dåben. Stroferne viser, at Fadervors placering i dåbsritualet før overøsningen og døbeordene ikke mere gav virkelig mening for Grundtvig, men de kan læses sådan, at han på 
denne tid alligevel prøvede at redde den overleverede placering ved at forstå den som udtryk for en stammen, altså en tøvende, usikker tale, der måske udtrykker den af syndefaldet formørkede, men bevarede gudbilledlighed.

I Grundtvigs nævnte prædikener fra 1839-1842 optræder udtrykket "Guds Børn" igen og igen, gerne forbundet med dåben, ${ }^{11}$ og en særlig sammenhæng med Fadervor antydes første gang i $1839 .{ }^{12}$ Selve Abba-stederne synes først at dukke op i 1842. I Grundtvigs prædiken til 5. søndag efter påske 1842 over teksten om bønhørelse i Jesu navn (Joh 16,23-28) bliver "Abba, Fader!" forstået som Fadervor: Jesus havde nok lært apostlene Fadervor, men de kunne endnu ikke bede bønnen i Jesu navn og derfor blive bønhørt, før de efter opstandelsen modtog "Aanden, der lærde dem at raabe Abba, Fader! at sige "Fader vor!" til Himlens Gud, saa Han kunde høre, det var Hans Børn, der kaldte, høre sin Søns Røst, i hvem Han har sin Velbehag, og hvem Han derfor altid hører!!”13 I sin prædiken til 8. søndag efter trinitatis 1842 er epistelteksten Abba-stedet i Rom 8,14-17, hvorfra Grundtvig gentager de første vers; evangelieteksten drejer sig om de falske profeter (Matt 7,15-21), men i det følgende kæder Grundtvig børneevangeliet sammen med dåben, den sønlige udkårelses ånd og Joh 1,12-13:

Og see, m. V. da nu al christelig Erfaring har lært og skal fremdeles lære, at hvem der ikke vil annamme Guds Rige som et lille Barn, kommer aldrig derind, hvem der ikke vil blive et Guds Barn i Daaben, uforskyldt, af Guds Naade og Barmhjertighed, bliver det aldrig, faaer aldrig den sønlige Udkaarelses, den himmelske Barnligheds Aand, som giver os

11. Holm et al. (2003). - Hele motivkredsen med "Guds børn" udledte Thodberg, En glemt dimension $i$ Grundtvigs salmer - bundetheden til dåbsritualet (København: G.E.C. Gad 1969), 63-64 fra dåbsritualet og børneevangeliet (Mark 10,13-17): "Netop favnen og Fadervor er tilsammen baggrunden for talen om at have børnekår med Jesus - være barn sammen med ham, for i Fadervor er Gudsbørnene 'sambårne' med Jesus". At "børnekår" alluderer til Paulus, fangede Thodberg altså ikke. Hans henvisninger er for ensidige, men børneevangeliets store betydning for Grundtvig kan ikke betvivles, og bekræftes også i disse prædikener; det bruges - som også bemærket af Thodberg - til at begrunde barnedåben ( $f_{x}$ Holm et al. (2003), bd. 1, 118 (19. søndag efter trinitatis)), men kombineres desuden tit med "Guds børn"-passagerne hos Paulus, fx Holm et al. (2003), bd. 1, 441-443, der forbinder Rom 8,17 med børneevangeliet.

12. Holm et al. (2003), bd. 1, 98: "i Daaben gienfødte til Hans Børn, saa vi af Hjertens Grund kan kalde Ham vor Fader” (15. søndag efter trinitatis 1839); sml. hertil også oplysningen om Grundtvigs note om Kingoverset om Fadervor i bd. 4, 47. 13. Holm et al. (2003), bd. 3: 209-214, citat 209; 213 skriver Grundtvig, at "i vor Troes-Bekiendelse og i Herrens Bøn, Fadervor, har vi to Ord af Herren, der skinner som en Lampe i Mørket"; 214 forbindes allusioner til børneevangeliet og "den sønlige Udkaarelses Aand". 
Magt til at være Guds Børn og af Hjertet kalde Himmelens og Jordens Skaber vor Fader, tillidsfuldt med Herren og hele hans Menighed at bede vort Fadervor; ... (Holm et al. 2003, bd. 3: 305-308 [306]).

Endelig skal vi bemærke Grundtvigs prædiken til 11. søndag efter trinitatis 1842; i den første del hentyder Grundtvig til bede-og-banke-bønnen i det daværende dåbsritual, og dernæst identificeres Abba-råbet atter med Fadervor:

... og da at bede i hans Navn, som sagde til os alle i Daaben: beder, saa skal eder gives, og naar det da lyder fra deres Læber, som udsendtes til at forkynde Evangelium: lader os alle bede! da føle alle Christne, at de maae ikke giøre en Røverkule af deres Hjerte, men skal giøre et Bedehuus deraf, hvor Faderen tilbedes i Aand og Sandhed, i det vi, med alle Guds Børn bede et Fadervor af Hjertensgrund: raabe: Abba Fader! (Holm et al. 2003, bd. 3: 324).

Særligt vigtig er dog sidste del af prædikenen, fordi Grundtvig gør det klart, at trosbekendelsen ved dåben følges af Helligåndens gave, og at vi først da får magt til at blive Guds børn og bede Fadervor:

Men det er vel at mærke, at den Tro paa Vorherre Jesus Christus, som giør, at vi kan bede i Hans navn og bønhøres for Hans Skyld, det er ingenlunde enhver Tro, som Mennesker kalde saa, men kun den Tro paa Faderen og Sønnen og den Hellig-Aand, som vi alle skal ved Daaben bekiende, og som da ogsaa maa være i vort Hjerte, naar der ikke skal være svig i vor Mund, thi kun naar vi har denne eneste ægte og sande christne Tro, kun da skiænker Gud os den Hellig-Aand, som giør levende, udsender sin Søns Aand i vore Hjerter, som vidner med vor Aand, at vi er Guds Børn i Christo Jesu vor Frelser, vidner saa kraftig og levende, at vi faae Magt til at være Guds Børn og raabe: Abba, Fader! Da, men ogsaa først da, kan vi bede i Jesu Navn og er da aldrig forlegne for, hvad vi skal sige, thi vor Herre Jesus har selv lagt os Ordene i Munden, og vi kiende dem alle fra Barnsbeen, saa det giælder kun om at de blive levende i vor Mund og i vort Hjerte, saa den Himmelske Fader kan see, vi tilegner os dem, som Hans Børn i Christo Jesu! Fadervor! (Holm et al. (2003), bd. 3, 329-330).

Den rækkefølge, som Grundtvig her opstiller, er selvfølgelig på den ene side ikke en konkret anvisning på en ændring af dåbsritualet, idet der jo er tale om den daglige virkeliggørelse af dåben i det personlige trosliv, men da det på den anden side er selve dåben, der på ny ak- 
tualiseres i den troende, ${ }^{14}$ er det nærliggende at tænke sig, at denne rækkefølge også må gælde i dåbsritualet.

I afhandlingen Herrens Bøn "Fadervor" fra 1855, der også blev en del af Den Christelige Børnelardom, finder man denne teologi om dåb og Fadervor klarest og mest samlet fremstillet. Afhandlingen viser, at vished eller sikkerhed var grundlæggende i Grundtvigs dåbsteologi. Den indledes med en hentydning til Luk 11,1-2 (VU 6, 49):

At "Fadervor", som Vorherres Jesu Christi egen Bøn, netop [sic] gjort til
at lære hans Discipler, hvordan de skal bede, hører ret egentlig til den
"Christelige Børnelardom" ... men ... man tog sig den Sag saa let, da
aldrig nogen af os kan have en velbegrundet Sikkerhed paa at være et
"Guds Barn" uden at have søgt denne Sikkerhed netop i vort "Fadervor"!

Frelsesvisheden skal vi altså søge, ikke i os selv, men i Fadervor, og igen bliver det klart, at Fadervor er uadskillelig fra dåben. Fadervor er nok en del af enhver gudstjeneste, men tilknytningen til dåben er anderledes, for det er her, Jesus lærer os bønnen og dermed giver os magt til at være Guds børn, som Grundtvig (VU 6, 50) siger, alluderende til Joh 1,12: “Fadervor' ... hører nødvendig og uadskillelig til Daaben efter Herrens egen Indstiftelse, saa ved Daaben larer Herren selv alle sine Discipler at bede, og giver dem med det samme, i Daaben, Magt baade til at vare Guds Børn og til at bede som Guds Børn,”...

Det er således gennem bønnens henvendelse til Gud som Fader, at relationen til ham virkeliggøres, så vi er hans børn; ved at have fået Fadervor har vi selv fået magt til at opnå denne bekræftelse, men den hviler på det objektive, at Jesus har lovet os status som børn, når vi er døbte på vores ja til dåbspagten; dette siger Grundtvig (VU 6, 50) også, idet han citerer Gal 3,26-27 og dermed gør det klart, at der er en sammenhæng mellem Paulus' "Guds børn”-tema og Fadervor:

Herrens Bøn "Fadervor" kommer følgelig til os alle ved Daaben, først og fremmerst som den Forsikkring af Herrens egen Mund, at naar vi troer i vort Hjerte, hvad vi ved Daaben bekiender med vor Mund, og er døbte derpaa i Faderens og Sønnens og den Helligaands Navn, da er vi sandelig Guds Børn, som skrevet staaer: I er ved Troen alle Guds Børn i Jesus Christus, thi I, saamange som er Christus tildøbte, I er Christus ikladte.

Der er også et subjektivt element i denne sikkerhed, fsv. den er noget, der skal være en levende indre erfaring (VU 6, 50):

14. At Grundtvig så Fadervor som det daglige pant på dåben, eller at den kristne gennem sit liv genoplevede dåben rituelt gennem denne bøn, blev også med rette fremhævet i Thodberg (1969), 53, 59, 76. 
det er ganske vist, at Ingen af os kan af Hjertens-Grund med Tillid og Fortrøstning kalde Himmelens og Jordens Skaber "vor Fader", med mindre vi føler os sikkre paa, at vi er Hans Børn, hvorfor da ogsaa Apostelen Paulus udtrykkelig vidner, at det er kun med den sønlige Udkaarelses Aand vi kan raabe: Abba, Fader! til Gud, idet Hans Aand vidner med vor Aand, at vi er Guds Børn.

Citatet fra Rom 8,15-16 viser ikke blot, at Grundtvig antog, at Abba-råbet hentyder til Fadervor, men også at Grundtvig genfandt foreningen mellem Jesu objektive forsikring i dåben og det troende hjertes personlige vished i Paulus' udsagn om, at Helligånden vidner sammen med $(\sigma v \mu \mu \alpha \rho \tau v \rho \varepsilon \tilde{i})$ vores ånd.

Det er klart, at Grundtvig produktivt bruger den lutherske tanke, at dåben varer ved hele livet, idet troen skal holde fast i dåbens løfte, når han skriver (VU 6, 50-51):

Derfor er Herrens Bøn "Fadervor" som han selv ved Daaben lægger os i Munden til at være vor daglige Bøn, os et guddommeligt Pant paa vor Gienfødelse i Daaben til Guds Børn ... Herved opgaaer der da et deiligt og skinnende Lys over to store Dunkelheder, som det hidtil var for os Alle, deels, hvori vi skulde finde den udvortes guddommelige Forsikkring om, at vi i Daaben efter Herrens Indstiftelse gienfødes til Guds Børn, og deels, hvorpaa vi skulde kiende Guds Aands indvortes Vidnesbyrd med vor Aand, at vi er Guds Børn; thi nu seer vi, at det samme "Fadervor", som, naar vi ved Daaben modtager det af Herrens egen Mund, er den udvortes guddommelige Forsikkring om vor himmelske Børne-Ret, det samme Fadervor bliver, naar vi føler os istand til at bede det af Hjertens-Grund, Kraft-Beviset paa, at vi er Guds Børn, altsaa den guddommelige Fader-Aands Vidnesbyrd med vor Aand, ...

Tydeligvis har Grundtvig savnet og søgt et konkret ord at kunne holde sig til som udtryk for dåbsløftets vedvarende realitet, og dette stemmer med, at han i slutningen af afhandlingen anfører, at det varede længe, før han fandt frem til sit nye syn på Fadervors rolle ved dåben (VU 6, 56).

I den øvrige del af afhandlingen forklarer Grundtvig, at Fadervor både må være enhver kristens individuelle bøn og hele menighedens bøn, og selv om man også kan bede andre bønner, er Fadervor den fuldkomne bøn, hvilket han prøver at vise ved en gennemgang af dens indhold. Derefter følger igen en vigtig teologisk overvejelse:

Men ligesom det nu ene og alene er Guds Faderlighed, der kan meddele os Villien til at bede "Fadervor" rettelig, saaledes er det ene og alene i 


\begin{abstract}
Vorherres Jesu Navn, at der kan meddeles os Magt baade dertil, og i det hele til at vare Guds Børn, og det har sin dybe Grund deri, at Vorherre Jesus Christus er Gud-Faders eenbaarne Søn, hvad der vel ved første Øiekast synes at udelukke os fra Børne-Retten i den himmelske Faders Huus, men viser dog kun, nøiere betragtet, Nødvendigheden af at troe paa Guds eenbaarne Søns Navn og af at bede "Fadervor" i hans Navn, for at kunne virkelig være Guds Børn og bede denne Bøn. Da nemlig Gud er fra Evighed til Evighed alt hvad Han er, saa maa Gud ogsaa, for i Sandhed at være Fader, være Fader fra Evighed, og de, som $i$ Tidens Løb skal blive Guds Børn, kan da kun blive det ved Troen paa Gud-Faders eenbaarne Søn fra Evighed, hvorfor Skriften ogsaa, ved at kalde os Guds udkaarede Børn, sætter forsvarligt Skiel mellem os selv og Gud-Faders egen, eenbaarne Søn (VU 6, 54-55).
\end{abstract}

Teksten opstiller på den ene side et skarpt skel mellem Gud og "os", mellem evighed og tid. Ontologisk er Gud evigt den samme og må derfor evigt være Fader, ligesom Jesus Kristus derfor evigt må være Søn, den enbårne Søn. Når Grundtvig her taler om frelse ved troen på den enbårne Søns navn, alluderer han til Joh 3,18 (sml. Joh 1,14.18; 3,16; 1 Joh 4,9), mens talen til slut om "Gud-Faders egen ... Søn" formodentlig sigter til ííov vioũ i Rom 8,32. Heroverfor står menneskene; de kan for en umiddelbar betragtning ikke være Guds børn, når Faderen har sin egen, ene Søn. Alligevel kan det at være børn "meddeles" dem, de kan blive adopterede ("udkaarede") børn, et udtryk, der netop markerer en tydelig forskel til Jesu evige væsen som Søn.

Overvejelsen har således sine klare rødder i Bibelen, men dens endelige udformning må søges i patristikken. Det drejer sig om en ontologisk forståelse af Gud ("Gud er fra Evighed til Evighed alt hvad Han er”), men der indgår også ideen om korrelation (hvis man siger om Gud, at han er relateret til en anden, må denne også være evig), brugt om forholdet mellem Faderen og Sønnen. Den evige Søn sættes som forskellig fra de adopterede sønner, og ^ó $\delta \varsigma$ bruges til at udtrykke denne forskel. ${ }^{15}$ Det er dog ikke det samme som at sige, at Grundtvig her behøver at have læst kirkefædrene, for treenighedsteologien blev jo videreformidlet gennem hele middelalderen og tidlig moderne tid.

15. Allerede Origenes forstod forholdet mellem Faderen og Sønnen som korrelation, muligvis inspireret af Aristoteles' kategori relation, $\pi \rho \rho_{\varsigma} \tau \imath$ (Cat 7b15), jf. Peter Widdicombe, The Fatherhood of God from Origen to Athanasius (Oxford: Clarendon Press 2000), 69-76, 91. Fader-Søn-forholdet som korrelation blev brugt som biskop Alexander af Alexandrias argument mod Arius; Alexander var ifølge Widdicombe den første, der brugte det paulinske udtryk îoı til at skelne mellem os, der ikke er Faderens egne børn, og Sønnen, der er Faderens egen Søn (ibid., 130-137). Hos Alexanders efterfølger, Athanasios, bliver hele denne argumentation central, jf. ibid., 145-249 passim. 
Den umiddelbare fortsættelse viser bl.a., at Grundtvig var helt på det rene med, at vio $\theta \varepsilon \sigma i ́ \alpha$ betyder "adoption":

\begin{abstract}
Naar imidlertid denne Udkaarelse skal være en sand Atledning og Knasatning, der virkelig giver os Børne-Ret og evig Arve-Ret til Guds-Riget, da maae vi ikke blot oprindelig staae i et saadant Forhold til Gud-Faders eenbaarne Søn, ved hvem Alt er blevet, at vi kan have fuldkomment baade andeligt og hjerteligt Fallesskab med ham, men det maa ogsaa være Troens Hemmelighed, at dette Fællesskab indtræder ved Troen, ... (VU 6, 55).
\end{abstract}

"Knæsætning" er et ord, dannet i tilslutning til oldnordisk knésetningr, om adoptivsøn eller -datter (ODS 10, 951); "Ætledning” betyder tilsvarende også adoption (ODS 27, 1412-1413). Grundtvig ønskede at bruge ægte nordiske ord. At Jesus Kristus er evig, betyder også, at han er skaber (jf. Joh 1,3), og derfor har "udkårelsen" sin grund i, at vi fra begyndelsen, "oprindelig", er skabt til gennem enheden med ham at være Guds børn, ${ }^{16} \mathrm{og}$, forklarer Grundtvig i fortsættelsen, efter genoprettelsen i dåben af det oprindelige forhold skal vi gennem bønnen Fadervor nå til enhed med ham ved troen i Helligånden.

$\mathrm{Nu}$ er det klart, at når Jesus giver os Fadervor i dåben, og det kun er gennem modtagelsen af Helligånden, udkårelsens Ånd, vi kan råbe Abba eller Fadervor, giver det ingen mening, at Fadervor i ritualet blev bedt, før barnet eller den voksne var døbt. Afhandlingen rummer ikke konkrete forslag til ændringer i ritualet, men dens teologi peger kun den vej. Det var umuligt for apostlene at bede i vor herres Jesu navn, før de havde fået Helligånden, og det er umuligt for os, siger Grundtvig (VU 6, 55). Men det er også klart, at den dialektiske teologis polemik mod "sikkerhed" ikke er relevant for at forstå Grundtvig. Hvis mennesket grundlæggende også er et følende og erfarende væsen, er det utroværdigt at benægte, at Guds frelse også er en erfaringssag, og hos Grundtvig var dette i hvert fald synspunktet. I en prædiken til 5. søndag efter påske 1841 talte Grundtvig fx om, at "skiøndt Troen vist nok

16. At vi egentlig er skabt til at være knyttede til Faderen gennem Sønnen og dermed fra begyndelsen til at være Guds børn, er velkendt som afgørende i Grundtvigs teologi; se fx afhandlingen Det medfodte og gienfodte Menneskeliv i Den Christelige Børnelardom, VU 6, 100-109; denne kontinuitet mellem det skabte, faldne og genløste menneske kunne Grundtvig også udtrykke ved hjælp af lignelsen om "den fortabte søn" eller "Om en forloren Søn", som den hed i Christian VI-Bibelen, fordi der dér netop er tale om en søn, se fx Det christelige Agteskab i Den Christelige Børnelardom, VU 6, 126-128; ligesådan i prædikener fra 1839-1840, se Holm et al. (2003), bd. 1, 133-134 (vi genindtræder i dåben i vores naturlige, sande forhold og får vor tabte arveret tilbage), 406, eller N.F.S. Grundtvigs Sidste Pradikener. I Vartov Kirke 1861-72 (Et Udvalg af C.J. Brandt) (Kjøbenhavn: Karl Schønbergs Forlag 1880), bd. I, 12-13 (i det følgende forkortet: Grundtvigs Sidste Pradikener (1880)). 
er skrøbelig hos Mange og Følelsen af Hjertets dybe Trang til Kraften fra det Høie kun svag, saa er det jo dog netop denne Tro og denne Følelse, der samler os, hvor Evangeliet forkyndes og lader os føle, der er godt at være”, og det fremgår, at Gud har dannet menneskehjertet sådan. Derfor kan der være en levende forbindelse mellem Gud og mennesket, en himmelstige hvor engle vandrer op med de gudfrygtiges bønner og ned med nådegaverne fra Gud (Holm et al. (2003), 224-225).

Den identifikation af Fadervor med Paulus' "Abba Fader!", som foreligger i afhandlingen Herrens Bøn "Fadervor", er i det hele taget meget udbredt i Grundtvigs tekster, og ofte enten betoner eller antyder Grundtvig, at Fadervor kun kan bedes af den døbte. ${ }^{17}$ I en tale,

17. Eksempler: Det i "Guds børn og Fadervor (I)", 115 nævnte brev til Elise Stampe fra 18/7 1856: “Da vi imidlertid ved Daaben finder baade 'Herrens Bøn' og hans 'Fredlysning' saa kan vi aldrig tvivle om, at Herren selv har lagt disse sin Munds Ord til Daaben, og naar vi betænker hvad det er, der maa skee ved Daaben, naar den i Sandhed skal være Gienfødelsens Bad, da opdager vi let, at Herrens Bøn og Fredlysning maa være de Ord af hans egen Mund, hvormed Synds-Forladelsen og den ny, aandelige Fødsel baade tilsikkres og skienkes os; thi naar Herren meddeler os $\sin$ Fred, da forliger han os med Gud, og naar han lægger sin Bøn i vor Mund, da giver han os dermed Magt til at være Guds Børn, da Ingen, uden i Sandhed at være Guds Børn, kan i Aand og Sandhed bede til Gud som deres Fader, hvorfor der ogsaa staaer skrevet, at det er kun ved den Helligaand, vi, forsikrede om vor himmelske Børneret, kan raabe: Abba, Fader!', Georg Christensen og Stener Grundtvig (udg.), Breve fra og til Grundtvig II: 1821-1872 (København: Gyldendalske Boghandel \& Nordisk Forlag 1926), 560. - Grundtvigs Sidste Predikener (1880) bd. I, 44 (11. søndag efter trinitatis 1861): "han meddeler os kun sin Bøn som en Faddergave til alle sine smaa Brødre og Søstre, som, naar de tilegner sig den som et evigt Livsord af Herrens egen Mund, faar deri det Vidnesbyrd af Guds Aand, at de er Guds Børn, som frit kan raabe: Abba, Fader! med den enbaarne Søn” ... - ibid., 145-146 (2. søndag efter helligtrekonger 1862): Den sørgelige vankundighed, at alvorlige kristne tror, at de skal sørge og græde, bliver først afhjulpet, når vi fæster vor kristne tro til dåb og nadver, "og da først og fremmest til Tros-Ordet i Daabs-Pagten, hvormed den Helligaand følger; thi da først levendegjør Aanden vor Tro paa Gud-Fader selv tredje med Sønnen, Jesus Kristus, og Helligaanden, og vidner med vor Aand i Herrens Bøn, at vi er gienfødte til Guds Børn i Kristus Jesus,” ... ibid., 557 (5. søndag efter påske 1866): "thi dette vort Fadervor er den første Ytring af dette Guds Børns Liv i Fællesskab med Faderen og med hans Søn Jesus Kristus”, ibid., bd. II, 92 (konfirmationssøndag 1868): "saa han kun kalder dem sine Børn, som tror paa hans enbaarne Søns Navn og som deri beder til ham som hans og vor himmelske Gud og Fader." - ibid., 127 (15. søndag efter trinitatis 1868) om Matt 6,26-29 (himlens fugle og markens liljer): "Og paa den anden Side har hverken Herren eller hans Tjenere glemt, at skjønt alle Mænd og Kvinder staar oprindelig i samme Forhold, som vi baade til Gud og Verden, altsaa ogsaa til Fugl og Blomst, saa er det dog kun Guds Børn, altsaa efter Syndefaldet kun de troende og døbte, der af Hjærtet kan raabe: Abba, Fader! til Himmelens og Jordens Skaber, og at alle andre Mennesker umulig, som Herren siger, kan have den barnlige Tillid til Gud, men maa plages af de verdslige Sorger." - GSV 5, No. 175 (fra 1862): "Bedes kan ei Fadervor/ Uden ægte Børnekaar,/ Arveret til Riget!” (strofe 2; Abba Fader! nævnes i strofe 4). 
som Grundtvig holdt ved det første grundtvigske vennemøde i København den 9. september 1863, smeltede Paulus' "Abba Fader!"-råb atter sammen med Matthæusevangeliets version af Fadervor, og her opstilledes en rækkefølge, der ikke svarer til 1783-ritualets, men til gengæld til mange af de overvejelser hos Grundtvig, der er fremdraget $i$ de foregående:

Efterat Salmen "Rejs op dit Hoved al Kristenhed" var sungen, sagde Grundtvig: Naar jeg paa det bestemteste har vedkjendt mig Tro paa Indstiftelsens Ord som Ordet af Herrens egen Mund, saa kan jeg dog ikke sige Farvel til denne Forsamling uden udtrykkelig at vedkjende mig, jeg mener, at derved ikke skal være nogen Tanke om noget Ord, jeg havde opfundet eller udrevet af sin Sammenhæng! Det er da, som vi alle ved, at, naar vi ved den Hellige Daab efter Herrens Indstiftelse ved dette lille Korsets Ord lodtages med Kristus, vi da forsage og afsige Djævelen og alle hans Gjerninger og alt hans Væsen, og tro paa Gud Fader almægtigste, Himmelens og Jordens Skaber, og paa Jesum Kristum, hans eenbaarne Søn, Vor Herre, undfangen ved den Hellig Aand, født af Jomfru Maria, pint under Pontius Pilatus, korsfæstet, død og begraven, nedfaren til Helvede, opstanden paa tredje Dag fra de Døde, opfaren til Himmels, siddende hos den almægtige Gud Faders højre Haand, derfra han skal komme igjen at dømme levende og døde, - og paa den Hellig Aand, den hellige almindelige Kirkeforsamling, de Helliges Samfund, Syndernes Forladelse, Kjødets Opstandelse og det evige Liv, - og at vi paa denne Tro ere døbte i Faderens, Sønnens og den Hellig Aands Navn, med den Forsikring, at vi da bleve gjenfødte til Guds Børn, saa vi kunne sige: Abba vor Fader, du som er i Himlene, helliget vorde dit Navn, tilkomme dit Rige, ske din Vilje som i Himmelen saa og paa Jorden, giv os hver Dag vort daglige Brød og forlad os vor Skyld som vi og forlade vore Skyldnere, led os ikke i Fristelse, men frels os fra det Onde, thi dit er Riget, Magten og Æren i Evighed, Amen! Saaledes ogsaa Herrens Fredslysning, da han lyste "Fred med dig!" og endelig Ordet, som er føjet til Brødet og Vinen: ... ${ }^{18}$

Til forskel fra 1783-ritualet er korstegnelsen her knyttet direkte til forsagelsen, ligesom Grundtvig som nævnt ovenfor ("Guds børn og Fadervor (I)", 118-119) havde hævdet det i et brev til Elise Stampe. Efter trosbekendelsen følger døbeordene og så forsikringen (det vil måske sige "den almægtigste Gud" osv.) ligesom i 1783-ritualet, men

18. Dansk Kirketidende 39-40 (1863), 647-648. Grundtvig fortsatte med nadverindstiftelsen og sluttede med at sige, at det var disse ord, der var mundtligt overleverede fra slægt til slægt. 
Fadervor er flyttet om efter dåben; til slut kommer fredlysningen ligesom i 1783-ritualet.

\section{Ekskurs: Fadervor og triaden tro, håb og karlighed}

Af interesse i nærværende sammenhæng er også Fadervors plads hos Grundtvig inden for triaden tro, håb og kærlighed fra 1 Kor 13,13. Dermed berøres et stort emne, som fører dybere ind i hjertet af Grundtvigs teologi, og som umuligt kan behandles i nærværende sammenhæng. Regin Prenter fremhævede, at Grundtvigs "sammentænkning af treenighed og gudbilledlighed" var hovedsagen i hans treenighedslære. Der er tale om en ejendommelig tænkning i treheder, der bl.a. indebærer, at det kristelige liv ifølge Grundtvig forløber som en vækst, der begynder med troen, vokser i håbet og fuldkommes i kærligheden. ${ }^{19}$ I denne sammenhæng identificerede Grundtvig Fadervor med "håbet". Det er næppe afklaret, hvordan denne identifikation kom i stand; Thodberg foreslog som anført, at den havde sammenhæng med citatet fra 1 Pet 1,3 i 1783-ritualet; her skal det nævnes, at "håbet" også er centralt i Rom 8,24-25, altså i nær sammenhæng med Abba-råbet og den "sønlige udkårelse".

Af relevans i nærværende sammenhæng er det kun, at Grundtvig talrige gange identificerer "mundsordene" med leddene i triaden tro, håb og kærlighed, og at det altid fører til, at Fadervor placeres efter døbeordene. Den videre kontekst og betydning af dette forhold ligger uden for undersøgelsens grænser. Her følger imidlertid en række eksempler:

Da det nu igien er Troes-Ordet ved Daaben, hvorigiennem den Helligaand, som den guddommelige Ordfører og Talsmand, personlig virker den tilsvarende Christen-Tro, saa maa det være Sonnen, som, skjult i Aanden, personlig virker Haabet giennem Daabs-Ordet og hans egen Bøn "Fadervor" i Menighedens Mund, og det maa være Faderen, skjult med Sønnen i Aanden, som giennem Nadver-Ordet personlig medvirker til den guddommelige Kiærligheds Opkomst og Væxt, ... (Den guddommelige Treenighed, VU 6, 152-153).

I afhandlingen Tro og Haab og Kierlighed fra 1858, der også indgår i Den Christelige Børnelardom, taler Grundtvig om "den Saliggiørel-

19. Grundtvig har givet en sammenhængende fremstilling af sin treenighedslære i afhandlingen Den guddommelige Treenighed, der også blev en del af Den Christelige Børnelardom, VU 6, 144-153. Se desuden Prenter, "Grundtvigs treenighedslære", N.F.S. Grundtvig. Theolog og Kirkelarer. Predikener og foredrag fra 200-àret, udg. Udvalget for Konvent for Kirke og Theologi (Skarrild 1983), 54-76. 
ses-Orden i Tro og Haab og Kiærlighed, som Herren selv har indstiftet”. Ånden lærer os trosbekendelsen, og "saaledes udtrykker Herrens $B ø n$, som han selv ved Daaben lægger sin Menighed i Munden, nemlig vort "Fadervor" som Børne-Bønnen i Guds Huus, klarlig Alt hvad det i Daaben gienfødte Guds-Menneske forlanger og forventer af sin himmelske Fader, udtrykker altsaa det christelige Haab," og nadveren udtrykker kærligheden (VU 6, 138).

Endnu et eksempel fra indledningen til Christenhedens Syvstjerne fra 1860, udg. Th. Balslev (København: Kirkeligt Samfunds Forlag 1955), 40:

\begin{abstract}
Betragter vi nemlig det christelige Grund-Ord af Herrens egen Mund til hele Folket, som et evigt Livsord, da bestaar det, ligesom Christen-Livet, af tre Hoveddele: Troes-Ordet, Haabs-Ordet og Kiarligheds-Ordet, Troes-Ordet nemlig i Daabs-Pagten, Haabs-Ordet i Daabs-Ordet, med Fredlysningen og Herrens Bøn, og Kiærligheds-Ordet i Herrens Bord-Tale ved den hellige Nadver, og kun hvor hele dette trefoldige, guddommelige Livs-Ord ved Troen og Aanden træder fuldelig i Kraft, kun der lever Menigheden ikke mere sit eget Liv, men hans, som er død og opstanden for os. ${ }^{20}$
\end{abstract}

I denne rækkefølge følges trosbekendelsen af døbeordene, og derefter kommer fredlysningen og Fadervor. Lidt tidligere i indledningen (udg. Balslev (1955), 36) bringer Grundtvig samme rækkefølge i forbindelse med Luther: "Morten Luther ... holdt ikke blot fast paa den apostoliske Troes-Bekiendelse, paa Daabs-Ordet, Fredlysningen, Fadervor og Indstiftelses-Ordet ved Nadveren, ..."

Fem mundsord findes også i Grundtvigs prædiken om de 5 brød i Matt 14,17 til midfaste-søndag 1863, men med fredlysningen efter Fadervor: "de fem Parter, hvori Herrens Munds-Ord til os er delt, nemlig Tros-Bekjendelsen, Daabs-Udtrykket, Fadervor, Fredlysningen og Nadver-Ordet" (Grundtvigs Sidste Predikener (1880) bd. I, 233). Denne rækkefølge er også underforstået i Grundtvigs "Samtale med Børnene" ved konfirmationen 1. søndag efter påske 1866, ibid., 537: "Dette Livets Ord taler Herren til os ved Daaben og Nadveren, først som et Troens og Haabets og dernæst som Kjærlighedens Ord." I det følgende (538) sagde Grundtvig til konfirmanderne: "Nu derimod spørger jeg dristig efter Herrens Mund enhver af eder: forsager du? tror du? Og besegler Pagten med det Vidnesbyrd: at hvem, der med et ærligt Ja tilegner sig Pagten, gjenfødes ogsaa i Daaben til et

20. Denne rækkefølge med fem mundsord, organiseret ud fra tro, håb og kærlighed, og hvor fredlysningen stilles før Fadervor, findes også i GSV 5, No. 147, strofe 7-9. 
Guds Barn, der frit kan kalde ham Fader med himmelsk Børneret baade her og hisset." Efter konfirmationen (ibid., 539) fremhævede Grundtvig igen triaden tro-håb-kærlighed knyttet til rækkefølgen trosbekendelse-Fadervor-nadverord.

\section{Konklusion og perspektivering}

På baggrund af denne undersøgelse burde der ikke mere være tvivl om, at et væsentligt element i Grundtvigs teologi, i den fuldt udviklede "kirkelige anskuelse", drejede sig om Fadervor som et "mundsord", som Jesus skænkede den nydøbte, og som derefter i den fortsatte kristelige vækst var et pant på dåben, både som Guds ydre forsikring om frelsen til den døbte og $\mathrm{i}$ dennes indre som Helligåndens vidnesbyrd sammen med den menneskelige ånd. Ifølge Grundtvig lå Fadervors betydning derfor efter selve dåben, og dette var bl.a. begrundet med de paulinske tanker om, at dåben indebærer en adoption som Guds børn, hvor de troende har modtaget Ånden, der sammen med dem råber Abba, Fader! til Gud. Det er ikke lykkedes at finde steder, hvor Grundtvig tillagde Fadervor betydning som en forbøn inden dåben, og der er derfor heller ingen grund til at betvivle, at det var Grundtvigs intentioner, som det 19 . århundredes grundtvigianere fortsatte, når de arbejdede for at flytte Fadervor hen efter dåben. Fadervors nuværende placering i folkekirkens dåbsritual er altså en konsekvens af Grundtvigs teologi, og takkebønnen "hvori du gør os til dine børn" i begyndelsen af ritualet udtrykker netop den paulinske idé om dåben som en adoption, som Grundtvig forbandt med, at Fadervor først måtte meddeles den, der var blevet Guds barn i dåben.

Der kan imidlertid heller ikke peges på et sted, hvor Grundtvig eksplicit siger, at dåbsritualet bør ænd res, så Fadervor flyttes hen efter dåben. Om Grundtvig selv eller først hans tilhængere nåede frem til at drage konsekvensen af hans teologi, må derfor behandles i en anden sammenhæng, i forbindelse med spørgsmålet om Grundtvigs medvirken ved Peter Andreas Fengers alterbogsforslag fra 1874.

Men der er også et større perspektiv i Grundtvigs syn på Fadervor. Der kan ikke være tvivl om, at Grundtvig overordnet set tog fejl, når han mente at kunne drage historiske slutninger fra den teologiske betydning, som han fandt i ritualets led. Derfor er det værd at bemærke, at han på netop dette punkt alligevel kan have forstået Paulus-teksterne rigtigt, altså at Abba-råbet i Rom 8,15 og Gal 4,6 netop forudsætter, at Fadervor kun er en bøn for de døbte. Hvis denne forståelse af Paulus-stederne er rigtig, indebærer det, at de oldkirkelige 
forfattere, der hævdede, at Fadervor først måtte bedes af de døbte, fortsatte en tradition, der gik kontinuerligt tilbage til de paulinske menigheder; alternativt udviklede de en ny praksis ud fra deres forståelse af Paulus-teksterne. ${ }^{21}$ Det kan ikke udelukkes, at Grundtvig kan være blevet inspireret ved at læse nogle af disse oldkirkelige tekster, fx af Cyprian eller Ambrosius, men jeg har intet belæg fundet for det. ${ }^{22}$ Sandsynligvis var der tale om Grundtvigs egen selvstændige forståelse af Paulus, der evt. kan ses som parallel med de oldkirkelige forfatteres forståelse.

21. Jeg vil i et senere arbejde dokumentere denne oldkirkelige forståelse af Fadervor, men se i øvrigt Jeremias (1966), 55 n. 106, 64-65, 67-80, 152-171 (dette afsnit foreligger også i dansk oversættelse: idem, Fadervor $i$ lyset af den nyere forskning. Økumene 13 (Aarhus: Aros 1980)); Roy Hammerling, The Lord's Prayer in the Early Church. The Pearl of Great Price (New York: Palgrave Macmillan 2010).

22. Det kan i den sammenhæng nævnes, at Grundtvig var i besiddelse af en større patristisk bogsamling, bl.a. de her nævnte forfattere, jf. Fortegnelse over N. F. S. Grundtvigs Bibliothek, som bortsalges ved offentlig Auction i Kladeboderne Nr. 38 Mandagen den 29. Sept. $1873 \mathrm{Kl} .10$ (Kjøbenhavn: E.C. Løsers Bog- og Nodetrykkeri 1873), 17-22 (nr. 605-711). 